\title{
Fantasmas (IN)Tangíveis nos CONTOS DE MURILO RUbĩ̃o
}

\author{
MÁRCIA MARQUES DE MORAIS \\ Pontifícia Universidade Católica de Minas Gerais
}

\section{Resumo}

A partir do tratamento que Freud dispensa ao significante alemão unheimlich, será examinada a questão das epígrafes bíblicas no texto de Murilo Rubião, como recurso para dar voz a fantasmas do sujeito. Esse agenciamento do conceito de fantasma aponta a inegável possibilidade de leitura dos contos murilianos pela vertente da psicanálise (raríssima, no entanto). Travessias complexas da subjetividade, conflitos do sujeito são matéria sempre da memória de sua literatura fantástica, que trata, à exaustão, do conflito entre pulsão e sua regulação, entre indivíduo e seu entorno, representado, sobretudo, pela alusão aos laços familiares, à família, ao clã, como instância primeira do mal-estar. No entanto, no texto de Rubião, os fantasmas - inquietantes, estranhos - são familiarizados por um trabalho obsessivo com o código lingüístico, com a forma do texto que, previsto, ortodoxo, tradicional e clássico, faz convergir para si, como significante, um significado tensionado entre lógico e alógico/ilógico; real e supra-real, aquietando, ainda que fugaz e ilusoriamente, a estranheza.

\section{Palavras-chave}

Murilo Rubião; estranho e familiar; sujeito e sociedade; desejo e angústia; falta e linguagem.

\section{Abstract}

Taking as a starting point the treatment given by Freud to the German signifier unheimlich, the paper will examine the issue of the Biblical epigraphs in Murilo Rubião's text, a device used to give voice to the subject's phantom. The use of the concept of the "phantom" points to the undeniable possibility of reading Rubião's short-stories through psychoanalysis (however uncommon this may be). Complex crossings of subjectivity, as well as the subject's inner conflicts, are constitutive elements of Rubião's fantastic literature, a literature that deals extensively with the conflict between compulsion and its regulation, the individual and his/her surroundings, represented above all by the allusion to family ties, the family, and the clan, as the primary location of unease. Nevertheless, in Rubião's text, the phantoms - strange and uneasy - become familiar through obsessive work with the linguistic code and with the text's composition. The latter, at first expected to be orthodox, traditional, and classical, embraces, as signifier, a signified in a state of tension between the logical and the a-logical/illogical, the real and the supra-real, reducing, albeit fleetingly and illusively, the strangeness that pervades the author's writing.

Keywords

Murilo Rubião; strange and familiar; subject and society; desire and anguish; lack and language.

Se a obsessiva reescrita de seus contos é marca inconteste de Murilo Rubião, vale apostar também em leituras em processo do texto muriliano, cujas perspectivas têm oscilado entre uma visagem supra-real do mundo e uma visão da realidade sob o filtro do fantástico ou, metamorfoseando, uma visada da magia, a mascarar uma realidade. 
A oscilação da perspectiva carreia consigo, inevitavelmente, a modalização do tom da leitura que, embora produza sempre o espanto, ora é ouvido como o soar de trombetas apocalípticas ora se escuta como eco que vaticina ora é, ainda, tom de uma constatação anunciada ou de desolação e desânimo.

Estudiosos já nos mostraram que as epígrafes bíblicas se incumbiriam de orquestrar leituras. De todo modo, ainda que as afinações sejam múltiplas e, de certo modo, garantidas pelo texto, são elas também muito próximas, deixando desconcertado o leitor de Murilo Rubião, diante do sentimento de perplexidade...

Nesse sentido, mal iniciada, portanto, a leitura de textos de um mestre da chamada literatura fantástica, o sentimento de estranheza capta o leitor. É que se escuta uma "voz epigráfica" que supõe, como sói acontecer com qualquer processo de leitura, uma outra voz que, intersubjetivamente, responda a ela; mas, no caso do nosso autor mineiro e suas epígrafes, essa voz resta como interrogação, pois as narrativas que se lhe seguem não chegam a reafirmar ou negar ou comentar aquilo que se lhes antepôs, frustrando-se, pois, uma expectativa e, como tal, instalando-se a estranheza, mais ainda porque, todas bíblicas, as epígrafes, de certa forma, são familiares ao leitor.

Nessa atenção que aqui se dá às epígrafes, vale ressaltar, como próprio dos textos murilianos, ainda outro fator causador do sentimento daquele estranho que "contém" o familiar tal como se experimenta no texto freudiano Das Unheimliche. Trata-se da recorrência, da repetição de epígrafes, sempre, obsessivamente bíblicas, confirmando o que Freud escreve no artigo de 1919: "O estranho é aquela categoria do assustador, que remete ao que é conhecido, de velho, e há muito familiar". ${ }^{110}$

Aliás, a repetição - e, por ora nos reportamos tão-somente à recorrência de processos de escrita - na produção muriliana é absolutamente concreta e concretizável: não bastasse sua "fixação" no texto bíblico como fonte epigráfica, reescrever obsessivamente o mesmo no afã de se estar escrevendo um outro, de buscar uma melhor forma, não seria incorporar, no próprio ato de escrever, a "compulsão à repetição" de "Para além do princípio do prazer" e, dessa maneira, dar forma ao "estranho/familiar"? 111

Sabemos todos que, dos 89 contos publicados, restam, como originais, apenas 32, tendo ficado um deles inédito até $1998,{ }^{112}$ fazendo ver que o tempo da escrita é, indubitavelmente, um tempo de re-escrita, de repetição.

Essas observações já mereceram atenção da fortuna crítica do autor. Davi Arrigucci ${ }^{113}$ percebe, sob o sugestivo subtítulo "Multiplicação e esterilidade", que a modificação de "uma obra tão breve [...] no decorrer do tempo", se, aparentemente, busca a perfeição da escrita e faz da criação um processo incessante, esse movimento seria "um tanto ilusório, como se entranhasse uma dificuldade inicial e apenas imitasse o giro recorrente do carrossel em torno do mesmo eixo". 114

Ainda relativamente às epígrafes, Arrigucci continua escrevendo:

Confirmando esse movimento repetitivo, as epígrafes bíblicas voltam infalivelmente. A Bíblia aparece literalmente como o Livro dos livros, o repertório ilimitado de todos os temas, uma espécie de fonte perene, onde os argumentos estão

\footnotetext{
${ }^{110}$ Sigmund Freud, "O estranho", in História de uma neurose infantil e outros trabalhos, trad. Jaime Salomão, Rio de Janeiro, Imago, 1976, p. 273-314. (Edição standard brasileira das obras psicológicas completas de Sigmund Freud, XVII). A citação encontra-se à p. 277.

${ }^{111}$ Sigmund Freud, "Além do princípio de prazer", in Além do princípio de prazer. Psicologia de Grupo e outros Trabalhos, trad. Cristiano Monteiro Oiticica, Rio de Janeiro, Imago, 1976. (Edição standard..., XVIII).

${ }^{112}$ Trata-se de “A diáspora”. Cf. Vera Lúcia Andrade (org.) Contos reunidos, São Paulo, Ática, 1998.

113 Davi Arrigucci Jr., "Minas, assombros e anedotas (Os contos fantásticos de Murilo Rubião)", in Enigma e comentário: ensaios sobre literatura e experiência, São Paulo, Companhia das Letras, 1987, p. 141-65.

${ }^{114}$ Idem, ibidem, p. 151.
} 
sempre à mão, para serem colhidos e reescritos, reatualizados na recorrência perpétua dos tempos. ${ }^{115}$

Já em Schwartz ${ }^{116}$ vamos ler, no prefácio de $O$ convidado, que o uso de epígrafes é "a mais notável das construções formais e temáticas na obra de Murilo Rubião", constituindo "um paradoxo provocado pela tensão do seu próprio status, autônomo e ao mesmo tempo dependente, em relação ao texto-base (o conto)". 117

Atentando-se para essa primeira fala bebida em Schwartz, já se percebe que aqui também a epígrafe contribui para o efeito de uma "contradicção", pois estabelece um campo tensionado pela simultaneidade de autonomia (dela mesma, epígrafe) e dependência (do texto). Ao examinar as epígrafes que abrem cada um dos livros básicos de Murilo Rubião ( $O$ ex-mágico, de 1947, Os dragões e outros contos, de 1965, O convidado, de 1974), o crítico declara que elas "revelam uma surpreendente sequiência narrativa que sintetiza a evolução temática de sua obra". ${ }^{118}$ Ora, se, de algum modo, tenta-se instaurar, no universo textual muriliano, alguma lógica, seja na idéia de uma certa "linearidade" da seqüência narrativa seja na idéia de progressão de "evolução temática", se entrevê, nessa interpretação, a possibilidade de leitura também do paradoxo, de um estranho e familiar simultâneos. É que a própria necessidade de buscar uma explicação da ordem da lógica para os textos, a partir de epígrafes, considerando-se os "três livros básicos" do autor, acaba denegando a frenética atividade de reelaboração e reescrita a que Murilo submete seus textos. Por meio dessa obsessiva operação, o autor dos contos desmancha, ele próprio, toda sorte de ordenação e embaralha textos tal qual as mãos do mágico e suas cartas de baralho.

Essa tentativa de diálogo com dois críticos da obra de Murilo Rubião, que se dedicaram, cada um a seu modo, a examinar-lhe as epígrafes, pretende, a partir de suas interpretações, buscar argumentos que sustentem a possibilidade de tais epígrafes poderem ser ouvidas também como antecipação, no texto muriliano, do sinistro que o assombra.

As epígrafes, pois, para Arrigucci, materializariam a repetição com sua recorrência infalível e, ousando uma analogia, elas também gravitariam em torno do ponto inicial de onde brotaram, da própria Bíblia, onde, segundo o crítico, estaria o pré-texto que a narrativa fantástica multiplica. Aí, na Bíblia, encontrar-se-iam o princípio e o fim das histórias, cujo meio multiplicado é o conto fantástico. Essas idéias de repetição, de movimento maquinal, de algo da ordem de uma dificuldade inicial entranhada, de um princípio e um fim convergentes, mas desgarrados de um meio que se multiplica, de descontinuidade acoplada a uma aparente ordem narrativa continuada e repetida são reiterações inequívocas da categoria freudiana, da "inquietante estranheza". 119

O mesmo se verifica com os estudos de Schwartz, embora neles se elejam outras entradas analíticas. "Do fantástico como máscara" já adianta, no próprio título, a questão do duplo, já que a máscara esconde uma face e mostra uma outra, instaurando a duplicidade, o duplo, tão caro ao estudo freudiano sobre o estranho. Assim, segundo o crítico, se as três fases murilianas seqüenciam-se e sintetizam-se, temática e sucessivamente, como máscaras da angústia existencial; como perplexidade e radicalização do absurdo diante da condição humana e, por fim, como aceitação do próprio absurdo, enunciada em voz profética, mascarada de futuro e encobridora de acontecimentos presentes, resta a instauração do perpétuo e circular acontecer das coisas, a engrenagem que não pára de rodar, figura também cara ao sinistro.

\footnotetext{
${ }^{115}$ Idem, ibidem, p.151.

${ }^{116}$ Jorge Schwartz, "Do fantástico como máscara", in Murilo Rubião, O convidado, São Paulo, Ática, 2000, p. 613 (prefácio).

${ }^{117}$ Idem, ibidem, p. 6.

${ }^{118}$ Idem, ibidem, p. 7.

${ }^{119}$ Expressão, na tradução francesa, do título original freudiano Das Unheimliche, que, no espanhol, aparece como "sinistro".
} 
Se a condução das argumentações é distinta nos dois críticos, ambos, no entanto, encaminham sua leitura para o viés histórico.

Para Arrigucci, "na essência do fantástico" retornaria, como "aparição fantasmal", a história, cujo peso passa a ocupar o primeiro plano, em virtude do distanciamento do mito, ${ }^{120}$ enquanto, para Schwartz, o tom pretensamente futuro da voz profética, ouvida nas epígrafes, particularmente de $O$ convidado, obra para a qual deságuam, segundo ele, as referidas sequiência narrativa e evolução temática, seria "máscara do futuro encobridora de acontecimentos presentes". ${ }^{121}$ É que, no texto de Rubião, a predição não estaria condicionada a coisa alguma para sua realização; logo, o conto se limita à tradução de sua profecia num tempo do presente. Assim, o que se prediz, vaticina, profetiza, em Murilo, não exige comprovação. É na "durée da escrita", ${ }^{122}$ conforme Schwartz, na linguagem mesma, que a profecia em potência da epígrafe se tornaria ato.

A própria escrita dos contos, pois, seria traduzida como um eterno presente, um acontecer perpétuo e circular de ações repetitivas, tal como o processo de escrita do autor, permitindo-nos reiterar o que dissemos antes sobre repetição e estranheza, no processo de produção de texto em Murilo Rubião.

É muito claro que a leitura da sociedade e suas mazelas se implicitam no texto fantástico. Em Murilo, são bastantes evidentes algumas "instituições" sociais ironizadas, tais como: a burocracia; o arrivismo; o controle e a pressão institucionais. No entanto, ao tratarem das epígrafes, levantando para elas hipóteses diferentes, demonstradas também diversamente, ambos os críticos deixam frestas para a argumentação em favor de uma leitura de cunho também psicanalítico, considerando-se os estudos freudianos sobre a inquietante estranheza, conforme se vem pontuando.

Para tentar um diálogo entre a voz epigráfica e textos psicanalíticos que tratam do estranhamento como efeito de sentido da ordem da subjetividade, tomarei, inicialmente, o texto de Oscar Cesarotto, "No olho do outro", apensado, como posfácio, ao volume Contos sinistros, de Hoffmann. ${ }^{123}$

Essa opção primeira se deve ao fato de convergirem para a produção textual de Hoffmann, não só o texto $O$ estranho (1919), de Freud, como, ainda, declaração do escritor Murilo Rubião de que seus contos "devem muito" a alguns escritores, entre os quais cita Hoffmann. $^{124}$

Há, também, na fortuna crítica de Murilo Rubião, alusões, ainda que pontuais, à questão da estranheza, do ponto de vista freudiano, seja pela remissão ao destrinçado signo unheimlich, pacientemente examinado por Freud, seja por remissões ao escritor alemão de contos fantásticos. Assim, Arrigucci se socorre do autor de "O homem da areia", substrato literário do trabalho de Freud, na referência que faz ao conto "Aglaia", personagem-título que, parindo ininterruptamente, dá à luz, por último, a filhas de olhos de vidro, "lembrando os bonecos maquinais e grotescos de E. T. A. Hoffmann". ${ }^{125}$

\footnotetext{
${ }^{120}$ Recorrendo a A. Rosenfeld a propósito de Kafka (Anatol Rosenfeld, "Reflexões sobre o romance moderno", in Texto/contexto, São Paulo, Perspectiva, 1969, p. 93), Arrigucci observa, ainda, "que o decisivo também para Murilo é o mito da impossibilidade de retorno ao mito" (D. Arrigucci Jr., "Minas, assombros e anedotas...", op. cit., p. 160.

${ }^{121}$ J. Schwartz, "Do fantástico como máscara”, op. cit, p. 8.

${ }^{122}$ Idem, ibidem, p. 8.

${ }^{123}$ Oscar Cesarotto, "No olho do outro", in E. T. A. Hoffmann, Contos sinistros - "O homem da areia" e "Os autômatos", trad. Ricardo Ferreira Henrique, São Paulo, Max Limonad, 1987, p. 91-171.

${ }^{124}$ Cf. entrevista transcrita em J. Schwartz, "Murilo Rubião: um clássico do conto fantástico", in Murilo Rubião, O pirotécnico Zacarias e outros contos, São Paulo, Companhia das Letras, 2006, p. 104: "Meus contos devem muito a Cervantes, Gogol, Hoffmann, Von Chamisso, Maximo Bontempelli, Pirandello, Bret Harte, Nerval, Poe e Henry James. Mas o autor que realmente me influenciou foi Machado de Assis, meu único mestre".

${ }^{125}$ D. Arrigucci Jr., "Minas, assombros e anedotas...", op. cit., p. 159.
} 
Já em 1974, Jorge Schwartz traz à baila o conceito freudiano da estranheza, afirmando: "Aliás, em $O$ convidado a atmosfera geral fica muito mais densa, mais viscosa, se comparada com as narrativas anteriores. O unheimlich freudiano (sensação sinistra) consegue atingir efeitos sociais bem mais corrosivos". ${ }^{126}$ Haveria, aí, um "atalho" no percurso freudiano sobre o estranho, ao convocá-lo, inicialmente, para os "efeitos sociais". Basta argumentar com um dos conceitos de unheimlich, transcritos no texto de Freud e forjado por Schelling " 'Unheimlich' é o nome de tudo que deveria ter permanecido... secreto e oculto, mas veio à luz"127 -, para perceber-se que, muito antes de o conceito de estranheza voltar-se para a sociedade, segundo a psicanálise, ele se volta para o sujeito e, portanto, seu movimento seria muito mais retrospectivo que prospectivo. Assim, o eterno presente, lido por Schwartz, circular, maquinal, faz sentir no perpetuo mobile do presentificado a persistência, a resistência, a reiteração, encobridoras de "acontecimentos passados", repetindo expressão de Schwartz. A partir, pois, de um futuro como máscara resiste um presente que, como repetição, aponta "a impressão assustadora que 'se liga às coisas conhecidas há muito tempo e familiares desde sempre", conforme Freud, no texto de 1919, citado por Roudinesco \& Plon. ${ }^{128}$ Esse estranho surge no cotidiano e na criação estética, a partir do despertar abrupto de certos complexos infantis, causadores da angústia, tais como o medo da castração, a figura do duplo, o movimento do autômato, capazes todos eles de "reativação das forças primitivas que a civilização parecia ter esquecido e que o indivíduo supunha ter superado". ${ }^{129}$

Nossa intenção em ler Murilo Rubião, sob a batuta da psicanálise, circunscreve-se, por enquanto, ao "emparedamento" das epígrafes, embora a simples nomeação dos complexos infantis despertadores da angústia já aponte para a propriedade de uma leitura psicanalítica dos contos fantásticos. Vale a pena avançar um pouco em direção a mais uma tentativa de interpretação da estratégia epigráfica, para mostrar que uma leitura psicanalítica não se contrapõe ou derruba uma outra bem urdida; antes, pelo contrário, serve para abrir novas sendas que reencontrem uma subjetividade enredada, "emparedada" também num texto e numa história.

Nessa direção, basta afinar o ouvido na escuta das epígrafes bíblicas, na certeza de que o sinistro se manifesta por meio dos sentidos, sensorialmente. E, se o privilégio dessa manifestação se dá na ordem do escópico, a audição propiciaria também "sensações perturbadoras com a maior facilidade, na medida em que um som, uma voz, um barulho podem suscitar a estranheza de não se saber a que remetem". ${ }^{130}$

Debruçando-nos, pois, sobre a questão da voz como detonadora da estranheza, vamos tentar, pari passu, acompanhar o raciocínio de Cesarotto, para fazer valer a idéia de que, em Murilo Rubião, as epígrafes podem ser lidas com uma outra modulação.

Assim, segundo a psicanálise, o sujeito submete-se ao que lhe é interditado, para se defender, por mais paradoxal que isso possa parecer, das consequiências terríveis e dolorosas da realização do seu desejo a acarretar a constante culpa. Obedecendo aos limites que lhe são impostos, o sujeito suporta o peso de sua consciência moral, tendo já introjetado regras que se lhe impuseram e que representam a vontade arbitrária e incoercível do Outro. No entanto, a fidelidade à norma que afastaria o castigo carreia consigo o mal-estar (também o da civilização, mas aqui ainda o do sujeito!), o sofrimento. $O$ superego age, pois, paradoxalmente, a favor (familiarmente) do sujeito e (estranhamente) contra ele. Cesarotto prossegue: "Os mandatos e exigências que precisam ser cumpridos cegamente não têm, pelo

\footnotetext{
${ }^{126}$ J. Schwartz, "Do fantástico como máscara”, op. cit., p. 12-13.

${ }^{127}$ Friedrich Wilhelm Joseph von Schelling, apud S. Freud, "O estranho", ed. cit, p. 281.

${ }^{128}$ E. Roudinesco, M. Plon, Dicionário de psicanálise, trad. Vera Ribeiro, Rio de Janeiro, Jorge Zahar, 1997, p. 383.

${ }^{129}$ Idem, ibidem, p. 383.

${ }^{130}$ Oscar Cesarotto, "No olho do outro", in E. T. A. Hoffmann, Contos sinistros, São Paulo, Max Limonad, 1987, p. 139.
} 
geral, outra consistência que o eco das vozes que os enunciaram, resíduos da época em que foram proferidas". ${ }^{131}$

É justamente aqui, nessa deixa psicanalítica, que se podem escutar as vozes das epigrafes bíblicas dos contos de Murilo Rubião. Tais epígrafes trazem para os contos o tom sinistro e deixam-no suspenso, em eco, repetindo-se. Talvez seja por isso que o leitor de tais contos se sinta desconfortável e paralisado, ouvindo nelas um tom oracular, que pede a resposta para um enigma indecifrável, indecidível. Se esse leitor tenta buscar respostas para elas nas próprias narrativas em que se deveriam/poderiam retextualizar não se satisfaz; se perscruta o próprio texto bíblico em que se contextualizariam também se frustra, conforme propõe Audemaro T. Goulart. ${ }^{132}$

Se há epígrafes mais "ajustadas" aos textos dos contos, como acontece, por exemplo, com "Aglaia" e seu parir ininterrupto, onde se ouve: "Eu multiplicarei os teus trabalhos e os teus partos (Gênesis, III, 16)"; ${ }^{133}$; com "Ofélia, meu cachimbo e o mar" em que o narrador conta, velhacamente, "episódios da crônica de [sua] família ou do mar, mostrando-se geneticamente marcado pelo "melhor sangue de uma geração de valentes marujos", e a epígrafe ressoa: "Este mar amplo, largo de braços, nele sulcam as naus, o dragão que formaste para zombar no mar (Salmos, CIII, 25 e 26)", ${ }^{134}$ ou, ainda, com "Marina, a intangível", personagem que, inequivocamente associada à mulher bíblica, inspira versos do narrador, que a "contextualiza" em trecho do Cântico dos cânticos (VI, 10), ${ }^{135}$ de onde é extraída a epígrafe, há outras que apenas tangenciam um "campo semântico" contemplado pelos contos, repetindo, um vocábulo do título. Dentre essas últimas, vale citar as epígrafes de "Os dragões" ("Fui irmão de dragões e companheiro de avestruzes, Jó, XXX, 29"); "O edifício" ("Chegará o dia em que os teus pardieiros se transformarão em edifícios; naquele dia, ficarás fora da lei, Miquéias, VII, 11"); "O lodo" ("Tu abriste caminho aos teus cavalos no mar, através do lodo que se acha no fundo das grandes águas, Habacuc, III, 15") e, ainda, vale aludir à de "Bárbara" que, embora não faça explícita referência semântica a elemento do texto, indiretamente contempla a personagem-título, agigantada, pela "mórbida mania" de pedir e engordar, quando nos faz ouvir: "O homem que se extraviar do caminho da doutrina terá por morada a assembléia dos gigantes (Provérbios, XXI, 16)". ${ }^{136}$

De qualquer forma, mais ajustadas aos contos ou apenas os tangenciando, tais epígrafes figuram ao lado de outras que, tematicamente, não se adiantam sobre o assunto a ser tratado ou o resumem, como seria próprio de tais inscrições; mostram, sim, sua motivação bíblica, pairando quase indecifráveis pelo/no conto, tateando-lhe o sentido. Aliás, Arrigucci, ao inscrever, no contexto bíblico, discurso primordial e gênese de todas as epígrafes, um princípio e um fim, destacando, como seu meio multiplicado, as próprias narrativas murilianas, leva-nos a reler as epígrafes também como resíduos da época em que foram proferidas a ecoarem, multiplicando-se, metamorfoseando-se, reeditadas nos contos.

Também em Schwartz se encontra guarida para defender as epígrafes como vozes de um alhures cuja função principal é enunciar. Se, para o crítico, elas oscilam entre autonomia e dependência, essa autonomia lhes daria a condição de serem porta-vozes oficiais do espaço/tempo de onde vieram. Além disso, sua dependência ao texto-conto de Murilo não implicaria a necessidade de, por exemplo, uma predição realizar-se no texto, que apenas a

\footnotetext{
${ }^{131}$ Idem, ibidem, op. cit.p. 145

132 A. Taranto Goulart, "A leitura epigráfica", in O conto fantástico de Murilo Rubião, Belo Horizonte, Editora Lê, 1995, p. 81-108.

${ }^{133}$ Cf. Murilo Rubião, O homem do boné cinzento e outros contos, São Paulo, Companhia das Letras, 2007, p. 55.

${ }^{134}$ Idem, O pirotécnico Zacarias e outros contos, São Paulo, Companhia das Letras, 2006. A epígrafe está à p. 40, e as citações, às p. 40 e 41.

${ }^{135}$ Idem, A casa do girassol vermelho e outros contos, São Paulo, Companhia das Letras, 2006, p. 25.

${ }^{136}$ Os quatro contos examinados se encontram em M. Rubião, O pirotécnico Zacarias e outros contos op. cit., na nota 25. As suas epígrafes se acham, respectivamente, às p. 50, 66, 75 e 26.
} 
repete, atualizando-a, presentificando-a. De novo, a voz incomoda porque paira, digamos assim, intransitiva. Schwartz, em seu texto, chama ainda a atenção para a diferença entre a epígrafe muriliana de tom profético e a própria profecia que, na tragédia grega, encarnada num desafio oral, exige ser desvendada pelas ações das personagens.

Essa última observação sobre as epígrafes tem por finalidade refletir sobre o trágico como elemento mediador de leitura entre narrativa e epígrafe, argumento usado por Goulart, ${ }^{137}$ para quem as epígrafes funcionariam como pequenos textos sintetizadores das narrativas que se lhes seguem, caracterizando-se como mise en abyme prospectiva em relação ao texto principal que deverá ser dublado por ela. No entanto, só um exame analíticointerpretativo será capaz de ver como a epígrafe anuncia o sentido do texto principal, iluminando-o. Essa análise e interpretação das epígrafes seria, então, operacionalizada pela idéia central que a identifica e, segundo a qual, elas se reuniriam em cinco conjuntos, representantes das idéias de advertência, desolação, perplexidade, reconhecimento e ameaça e que se identificam com os elementos do trágico. Embora a leitura epigráfica de Goulart se dedique em estabelecer, entre as epígrafes e os contos, uma relação mais transitiva, é forçoso observar que o crítico ressalva ser essa uma fase a posteriori de leitura e, portanto, acrescento, mais conceitual, mais cerebrina, já que a leitura intuitiva do texto muriliano aponta, inequivocamente, para o sentimento de desajuste entre o texto bíblico e as narrativas. Seria, justamente, nesse descompasso, suponho, que se ouviria a voz epigráfica residual, a instalar fantasmagorias, já que não se encontra, de imediato, uma outra voz que lhe venha em socorro, quer seja ela da ordem de uma constatação, de um aviso, de negação, de afirmação, de explicação, de dúvida etc. No caso da voz que perscruto, para neutralizar o fantasmático de uma outra voz que só ecoa, estou buscando a voz audível, a dicção da oralidade, a fala oracular que é como ouço as epígrafes dos contos murilianos, atravessando as narrativas em questão, ressoando aquém e além delas.

Essa voz bíblica, familiar, porque repetida e estranha, porque metamorfoseada de um contexto para outro, duplicada, funcionaria, na verdade, como "a voz obscena do 'supereu' [que] ressoa nas margens do inconsciente como um sino insensato, porém irremediável". ${ }^{138}$ Essa voz, instalando o sinistro, paralisa o sujeito, pois o ameaça e manieta.

O sinistro é reiterado, no decorrer de narrativas que privilegiam o supra-real e se representa pela repetição de situações sem-saída, pelo "emparedamento" de narradores e personagens; por metamorfoses incessantes e zoomorfismos, por animismos exacerbados, por magias extraordinárias; por angústias de toda ordem; por frustrações em buscas e esperas; por ausências súbitas e desencontros; pela vacuidade e pelo abissal; por carência e excesso; por repetição e desmesura; tentativa continuada de preenchimento de tempo e espaço; caráter espectral das personagens; por sentimentos de inadequação ao mundo etc. No entanto, parecenos especialmente relevante, no texto muriliano, dentre as muitas angústias que ele faz ler/sentir, a angústia da castração, grifada por Freud, "como eixo e divisor de águas". ${ }^{139}$ Nela se situa a convergência do desejo e da angústia; do heimlich e do unheimlich - o da ordem do interno, da casa, do doméstico, do familiar, do antes versus o da ordem do externo, do grupo, da sociedade, do estranho, do depois. A castração, categoria simbólica obviamente, opera com aquilo que, por familiar e íntimo, deverá ser rechaçado, não poderá ser permitido, e o que é da ordem da subjetividade passa a ser percebido como do outro, como alheio, produzindo, pois, o sinistro, o estranhamento.

\footnotetext{
${ }^{137}$ A. T. Goulart, "A leitura epigráfica", op. cit., p. 84-6.

${ }^{138}$ O. Cesarotto, "No olho do outro", op. cit., p. 145.

${ }^{139}$ Idem, ibidem, p. 123.
} 
A castração desperta a atenção no texto de Murilo Rubião, a partir do próprio processo de reescritura do autor, em sua luta incessante do fazer com o refazer, no afã de preencher uma falta inexorável, como observa Schwartz. ${ }^{140}$

Ela é bastante flagrante em contos como "O lodo" (texto estranhamente não republicado pelo autor em vida), em que, não por acaso, a personagem Galateu sonha com a decepação de seus mamilos, constatada no espelho, ao acordar. Não bastasse o corte sofrido por Galateu, a narrativa ainda se vale do espelho, onde a personagem constata a mutilação. Cesarotto, ${ }^{141}$ ao comentar o termo "sinistro" contrapondo-o a "destro", refere-se ao "estádio de espelho", de Lacan, para dizer que no espelho se representa a alienação do sujeito humano, embora a expectativa seja a de que, no espelho, a figura do indivíduo se integrasse como imagem especular. É que, paradoxalmente, se o espelho oferece a possibilidade de nos enxergarmos por inteiro, pagamos o preço de nos vermos como um outro. A figura que se reflete é a de um mesmo/outro, e a própria lateralidade é assimétrica - o esquerdo se torna direito, o sinistro será o destro; de novo, convivem um si e um outro; familiar e estranho. Ainda que essa seja uma fração de leitura de "O lodo", é lícito afirmar que o conto é prato cheio para a psicanálise, até porque ele trata de um (im)possível processo analítico, parodia o trabalho do psicanalista, denegando-o, e enfatiza o pantanoso lugar inconsciente. Sua epígrafe, bebida em Habacuc, III, 15, ecoa "o lodo que se acha no fundo das grandes águas", ${ }^{142}$ águas também maternas de onde peleja para parturejar-se o próprio sujeito.

Ainda se lê, em Rubião, a mutilação repetida nas mãos de "O ex-mágico da Taberna Minhota"; ${ }^{143}$ na navalha que, em "A flor de vidro", ${ }^{144}$ corta os cabelos de Eronides, cabelos e olhos surrealmente recompostos na imagem no espelho - de novo! -, depois de uma noite de amor com Marialice; na alegação estranha e matreira do narrador de "Ofélia, meu cachimbo e o mar" para se permitir ir morar no litoral, perto do mar, das águas e a desilusão que o aguardava no porto: "fraturei um dos pés e fiquei inutilizado para os trabalhos marítimos". ${ }^{145}$ Desnecessário apontar, nessas narrativas, a recorrência de categorias caras à psicanálise: cortes, em geral, e dos cabelos, em particular; a cegueira; as águas e os pés desiguais oedipus -, que não formam um par simétrico; a fragmentação/recomposição/fragmentação do corpo. As mutilações, ao decomporem a integridade do corpo, por si só instalam a estranheza e, do ponto de vista psicanalítico, concretizam a ruptura da unidade narcísica, fazendo brotar o que Freud chamou de "ferida narcísea". ${ }^{146}$ Dessa óptica, seria muito instigante buscar resposta para momentos na obra muriliana em que a um corte, um rompimento, uma falta, se sucede o nascimento/aparecimento de uma flor, como se se pensasse uma/a ferida.

Assim, se, em "O lodo", nos mamilos decepados de Galateu surgiram pétalas rubras, "as primeiras pétalas de um minúsculo girassol vermelho" surgem no ventre grávido de Belinha, após a morte de seu irmão Xixiu, afogado na represa, em "A casa do girassol vermelho". ${ }^{147}$ Aliás, as flores e seus nomes se repetem nos contos murilianos e se associam também a nascimento, criação: se "Aglaia"148 é nome de uma das três Graças, o é também de uma flor e, no conto, dá à luz desbragadamente, enquanto a personagem-título de "Botão-de-

\footnotetext{
${ }^{140}$ J. Schwartz, "Murilo Rubião: um clássico do conto fantástico", in Murilo Rubião, O pirotécnico Zacarias $e$ outros contos, São Paulo, Companhia das Letras, 2006, pp. 101- 110.

${ }^{141}$ O. Cesarotto, "No olho do outro", op. cit., p. 121.

${ }^{142}$ Cf. nota 27, p. 75.

${ }^{143}$ Cf. M. Rubião, O pirotécnico Zacarias e outros contos, São Paulo, Companhia das Letras, 2006, pp. 19-25.

${ }^{144}$ Idem, ibidem, p. $46-49$.

${ }^{145}$ Idem, ibidem, p. 40-5. A citação se encontra à p. 42.

${ }^{146}$ Cf. S. Freud, "Uma dificuldade no caminho da psicanálise", in História de uma neurose infantil e outros trabalhos, trad. Jaime Salomão, Rio de Janeiro, Imago, 1976, op. cit.p. 169-79; e Idem, "Alguns mecanismos neuróticos no ciúme, na paranóia e no homossexualismo", in Além do princípio de prazer. Psicologia de Grupo e outros Trabalhos, trad. Cristiano Monteiro Oiticica, Rio de Janeiro, Imago, 1976, p. 269-81.

${ }^{147}$ M. Rubião, A casa do girassol vermelho e outros contos, op. cit., p. 11-19. A citação encontra-se à p. 19.

${ }^{148}$ Cf. M. Rubião, O homem do boné cinzento e outros contos, op. cit., p. 55-63.
} 
Rosa"149 engravida todas as mulheres da cidade. Em "Marina, a intangível", um "cântico" paródico, uma ode muito especial à própria poesia, "os versos para Marina prescindem de máquina", e seus primeiros cantos se formam, despetalando-se rosas e solicitando-se, para os últimos, "girassóis, que não existiam e nem podiam ser desfolhados!". ${ }^{150}$

Nas flores, pois, a figuração da criação literária, do poético, como instância que tenta suprir a falta original, como sublimação. Argumente-se, ainda, com a flor azul que Eronides busca na mata para Marialice e com o próprio título do conto, "A flor de vidro", ${ }^{151}$ que a personagem luta para divisar. A flor azul lembra o "azulado pé de flor, da mais rara e inesperada: com entreaspecto de serem várias flores numa única, entremeadas de maneira impossível, num primor confuso, e, as cores, ninguém a respeito delas concordou, por desconhecidas no século", do conto "Um moço muito branco", de Guimarães Rosa. ${ }^{152}$ Essa lembrança pretende, tão-somente, recobrar estudo de Heloísa Vilhena de Araújo, ${ }^{153}$ sobre o conto roseano. A pesquisadora lê analogicamente "o azulado pé de flor" com a flor azul no relato de um estrangeiro que emociona o herói de Heinrich von Ofterdingen, de Novalis, o qual acaba encontrando-a em sonho. Para Araújo, a flor azul "torna-se o início de uma busca iniciática da origem, por intermédio da poesia". ${ }^{154}$ Parece-nos bem plausível essa leitura da flor azul para "A flor de vidro", de Rubião, e a aproximação das figuras da poesia - a flor azul - e da mulher - Marialice, também recorrente em "Marina, a intangível". Com ambos os contos, a relação flor/mulher/poesia concentra a referida convergência de desejo e angústia, que se ouve num dos contos: "porque neles o amor se nutria da luta e do desespero". ${ }^{155}$

Essa relação amorosa e desesperada se encena, como se vem frisando, no também angustiante processo muriliano de lutar com seu próprio texto. Essa luta talvez busque uma "estética" de naturalização, de familiarização do extraordinário, do estranho pela "neutralidade", "ortodoxia", digamos assim, do código lingüístico, de tal maneira que, na "forma", na "cristalização" da escrita, o estranho se renda a uma certa aceitação, enquanto, no efeito de sentido que ele produz sobre o sujeito, ele paire mesmo como voz que incomoda. Em "A casa do girassol vermelho", ${ }^{156}$ por exemplo, que reconta o mito do pai despótico da horda primitiva, mito inaugural da sociedade, conforme Freud, no "Totem e tabu" ${ }^{157}$ a construção do conto encena, pela forma com que organiza as referências às personagens, as misturadas relações de parentesco. Ao privilegiar referenciações a laços de fraternia, ("minha irmã Belsie; Xixiu, irmão dela; e o besta do seu irmão; minhas irmãs; elas [as irmãs] não são iguais às suas [outras irmãs] etc."), na alusão às personagens, obriga o leitor a proceder, ele mesmo, a um deslindamento da linguagem, para desmisturar as relações de parentesco que se dão naquele "universo". ${ }^{158}$ Mas o tom dessa nomeação indireta e perifrástica soa muito natural. Essa pretensa naturalidade com que, no texto de Murilo Rubião, conta-se o extraordinário, pode ser ouvida, por exemplo, quando se tenta preencher a angústia da falta com o excessivo, figurado em "Bárbara", ${ }^{159}$ personagem-título e adjetivo que, não por acaso,

\footnotetext{
${ }^{149}$ Idem, ibidem, p. 76-86.

${ }^{150}$ Cf. M. Rubião, A casa do girassol vermelho e outros contos, op. cit., p.25-33. As citações encontram-se, respectivamente, às p. 40 e 41.

${ }^{151}$ Cf. M. Rubião, O pirotécnico Zacarias e outros contos, op. cit., p. 46-9.

152 João Guimarães Rosa, Primeiras estórias, Rio de Janeiro, José Olympio, 1972, p. 99-104. A citação encontrase à p. 102.

${ }^{153}$ Heloísa V. Araújo, O espelho. Contribuição ao estudo de Guimarães Rosa, São Paulo, Mandarim, 1998, p. 141-8.

${ }^{154}$ Idem, ibidem, p. 147.

${ }^{155}$ Cf. M. Rubião, O pirotécnico Zacarias e outros contos, op. cit., p. 48.

${ }^{156}$ Cf. M. Rubião, A casa do girassol vermelho e outros contos, op. cit., p. 11-19. A citação encontra-se à p. 19.

157 Sigmund Freud, Totem e tabu e outros trabalhos (1913 [1912-13]), trad. Órizon Carneiro Muniz, Rio de Janeiro, Imago, 1974 (Edição standard brasileira..., XIII).

${ }^{158}$ Cf. A. T. Goulart, "Fantástico e realidade cultural em Murilo Rubião", em Suplemento. Belo Horizonte, dezembro 2006, Especial Murilo Rubião, p. 12-15.

${ }^{159}$ M. Rubião, O pirotécnico Zacarias e outros contos, op. cit., p. 26-32.
} 
aponta "quem ou o que é contrário a regras", que se excedia em pedir e engordar e em "O edifício", "monstro de ilimitados pavimentos" que continuava a ganhar altura, pelo trabalho dos empregados que "entusiasmados com as belezas das imagens do orador, pediam-lhe que as repetisse". 160

E o conto parece inverter o mito babélico em que pretensão e mistura das línguas instaura a desordem: "João Gaspar se enfurecia, desmandava-se com violentos insultos. Mas estes vinham vazados em tão bom estilo, que ninguém se irritava". ${ }^{161}$ Percebe-se, pois, que as construções de linguagem, representadas pelas "belezas das imagens do orador" e pelos "violentos insultos vazados em tão bom estilo", de algum modo, regulam e, por isso, possibilitam a construção do desmesurado edifício. Assim, medida e desmedida; regra e desregramento, em perpétuo conflito no texto de Murilo Rubião.

"O bloqueio", ${ }^{62}$ não por acaso, vira "o edifício" de ponta-cabeça, já que aqui a angústia não é mais a do excesso no preenchimento da falta; mas a da reiteração do que falha, falta, do abissal, da carência. Aqui se instalaria aquilo a que Lacan se referiu, na releitura do unheimlich freudiano, como o confronto do sujeito com "a falta da falta". ${ }^{163}$ Segundo a psicanálise, um fato exterior reativaria algo que, por familiar e íntimo, precisa ser afastado, no intuito de se projetar além da subjetividade e se perceber como alheio. Parece ser isso o que também acontece com Gérion, personagem do conto. Ele se defronta com a falta perdurável que instala a angústia, diante de uma máquina destruidora, que, incessantemente, faz ruir um edifício e seu pequeno apartamento, sua casa, para onde se mudara havia três dias, após separar-se de Margarebe, sua mulher, tendo, pois, sido instado a se afastar da filha, Seatéia. O "ir e vir da destruidora", por mais paradoxal que possa ser, atraíam Gérion, "que não suportava a espera, a temer que ela tardasse em aniquilá-lo ou jamais o destruísse", diz o texto. Para o tal movimento maquinal, de um autômato (categoria cara ao "Estranho"), convergiam, assim, desejo e angústia da personagem. Instala-se, sem grande dificuldade, a possibilidade de uma leitura do afastamento de algo da ordem da subjetividade - o familiar, figurado na casa abandonada, na mulher e na filha - e sua substituição por algo da ordem do alheio, do estranho - a máquina e seu poder destruidor, a quem se atribuem características humanas e, mais que isso, características femininas num contexto de desejo: "a máquina persistia em se esconder, não sabendo ele se por simples pudor ou se porque ainda era cedo para mostrar-se, desnudando seu mistério". ${ }^{164}$ Ainda uma vez, no texto muriliano, uma outra metáfora de mulher e, mais que isso, uma outra possibilidade de se figurar máquina e escrita. O efeito do apagamento de um "familiar" e a projeção da subjetividade em um "estranho", no outro, trazem a sensação sinistra produzida por um esfacelamento da realidade, conforme Cesarotto. ${ }^{165}$

Dessa óptica, a de esfacelar a realidade, sob a máscara composta, estruturada, do código lingüístico é que o texto de Murilo Rubião se produz, e "O bloqueio"166 confirma isso.

A angústia como matéria de seu texto é, sim, a angústia existencial de que nos falara Schwartz. No entanto, essa angústia, em primeira instância, é da ordem do sujeito, da subjetividade e, claro, ipso facto, acomete-o como sujeito societário, como sujeito histórico. Aliás foram Lacan e outros herdeiros de Freud, todos leitores de Kierkegaard e Heidegger, que "zelaram por vincular [...] a questão da angústia psíquica do homem à de sua angústia existencial”, segundo Roudinesco. ${ }^{167}$

\footnotetext{
${ }^{160}$ Idem, ibidem, p. 66-74. As citações encontram-se, respectivamente, às p. 72 e 74.

${ }^{161}$ Idem, ibidem, p. 74.

${ }^{162}$ M. Rubião, A casa do girassol vermelho e outros contos, op. cit., p. 66-72.

${ }^{163}$ J. Lacan, apud E. Roudinesco, M. Plon, Dicionário de psicanálise, op. cit., p. 383.

${ }^{164}$ Cf. M. Rubião, A casa do girassol vermelho e outros contos, op. cit., p.72.

165 O. Cesarotto, "No olho do outro", op. cit., p. 123.

166 Cf. Márcio Serelle, "Visões da máquina", Suplemento, Belo Horizonte, dezembro 2006, Especial Murilo Rubião, p. 22-25

${ }^{167}$ E. Roudinesco, M. Plon, Dicionário de psicanálise, op. cit., p. 383.
} 
Vale frisar, como recorrente, nos contos de Murilo, a tensão entre o indivíduo e seu entorno, representada, sobretudo, na alusão aos laços familiares, à família, ao clã, como instância primeira do mal-estar.

No próprio conto "O bloqueio", esse viés de leitura parece ter um forte apelo, ouvido, por exemplo, no soar incômodo do telefonema regulador de Margarebe e no eco da voz da mãe nas palavras da filha Seatéia, controladores de Gérion, cujo tom, diante da situação de cobrança, é irritadiço e agressivo. Findo o telefonema, o texto diz:

A ligação foi interrompida bruscamente. De início suspeitara e logo se convenceu de que a filha fora obrigada a lhe telefonar, numa tentativa de explorá-lo emocionalmente. Àquela hora estaria apanhando por não ter obedecido à risca as instruções da mãe [...]. Talvez a estimasse pela obrigação natural que têm os pais de amar os filhos. ${ }^{168}$

Os termos aqui destacados são reiterados por outros de igual teor, mitigados ao longo do conto, como em: "Gostara de alguém? - Desviou o curso do pensamento, fórmula cômoda de escapar à vigilância da consciência". ${ }^{169}$

As elucubrações de Gérion, quase inconfessáveis no contexto de uma sociedade civilizada, no que diz respeito à paternidade, ao mesmo tempo, se naturalizam, diante de uma construção, referencial e metafórica, que rui, ficando a linguagem muriliana de pé. Assim, no discurso do narrador, o amor paternal é uma "obrigação natural", e se aceita o mal-estar da tensão obrigação/cultura versus natural/natureza, de modo quase plácido. Perceba-se, por fim, a ironia, concentrada no termo "ordem" e no possível alemão unheimlich será examinada a questão das epígrafes bíblicas no texto de Murilo Rubião, como recurso para dar voz a fantasmas do sujeito. Esse agenciamento do conceito de "fantasma" aponta a inegável possibilidade de leitura dos contos murilianos pela vertente da psicanálise (raríssima, no entanto). Travessias substrato do texto freudiano sobre o estranho, na narração do motivo que levou Gérion a deixar casa e família: "Preferiu correr o risco a voltar para sua casa, que abandonara, às pressas, por motivos de ordem familiar". ${ }^{170}$

Assim se representa, na literatura fantástica de Murilo Rubião, o mal-estar no contexto familiar, tomado da mais estranha forma, mas apontando sempre o movimento do desejo a mercê do desejo do outro, seja em termos de sujeito seja de sujeito histórico. Assim também, a psicanálise, apontando, à exaustão, o embate pulsão e sua "regulação"; natureza/cultura; sujeito/sociedade, pensa as instituições e organizações sociais como locus do mal-estar, frisando-as, no entanto, como única possibilidade identitária.

\footnotetext{
${ }^{168}$ Cf. M. Rubião, A casa do girassol vermelho e outros contos, op. cit., p. 66 e 70.

${ }^{169}$ Idem, ibidem, p. 70.

${ }^{170}$ Idem, ibidem, p. 67.
} 